Book reviews

Infanticide and the Value of Life

Marvin Kohl, (Ed)

pp. 252. $\$ 15.95$

Prometheus Books

Buffalo, New York, 1978

Increasing control over living and dying has brought great benefits, but it has also created moral and ethical problems of great complexity. As never before, life and death decisions in medical practice have attracted the attention of philosophers, theologians, lawyers and 'professional ethicists'. In this volume on Infanticide, a number of distinguished contributors are joined by three practising doctors whose credentials allow them to write with authority on this complex and emotive issue. In his introduction Dr Kohl is careful to emphasise the distinction between malevolent and benevolent infanticide. It is the latter where the motive is to benefit or help the one who dies that is the focus of attention of most of the contributors. The special problems inherent in deciding the care of infants born with severely handicapping conditions are given special emphasis.

The book consists of four main sections and there are several appendices. In the first two sections infanticide is discussed from the religious, moral, ethical, anthropological, psychological and medical viewpoints. The third section deals with legal issues and the fourth is largely devoted to philosophical discussions on such topics as the value of suffering, voluntary death and meaningless existence, and the worth of human life. The appendices include the British Infanticide Act of 1938 and proposed legislation (by Arval Morris) 'relating to the administration of euthanasia to certain severely defective children suffering from an irremediable condition.' Finally, there is an annotated bibliography of recent relevant books and articles (mainly since r970).
In a review of this type it is not possible to do justice to the efforts of each contributor. My selection for special mention inevitably reflects my own bias. At times the philosophical arguments are difficult to follow and seem somewhat detached from the cruel tragedies that affect families here and now. Doctors involved in these problems are likely to find the first three sections of special interest and relevance. Opposing views are clearly expressed and the inevitable and necessary compromises are well argued. Joseph Fletcher argues the utilitarian view that justifies infanticide where the good to be gained outweighs the evil. On the other hand, Rabbi Jakobovits emphasises the Jewish commitment to the sanctity of human life which must outweigh all other considerations. Richard Brandt discusses the morality of infanticide and suggests that there is little moral difference between the abortion of a defective child or its killing after birth-a point of indisputable logic that has been taken up by parents of severely defective newborn infants and (for different reasons) by anti-abortion lobbyists. Dr Brandt suggests that 'we may expect that rational benevolent persons deciding which moral code to support would select one that required respect for the life of a normal child but would permit the termination of the life of a severely defective child'. He also emphasises a truth only too apparent to paediatricians-that once the basic decision not to sustain life is taken 'it is mere stupid cruelty to allow it to waste away gradually ....

Dr Peter Black tackles the difficult moral distinction between killing and letting die. $\mathrm{He}$ points out that the physician's own view of his role and responsibility will be crucial to any decision he makes. For example, the imperative to relieve suffering might allow killing as legitimately as it does letting die-both will be morally acceptable.

Drs Raymond Duff and Anthony
Shaw, a paediatrician and paediatric $\stackrel{\mathbb{Q}}{\circ}$ surgeon respectively, discuss these के issues from the cotside in the $\vec{P}$ Special Care Nursery where some of $?$ the most difficult and most poignant $\overrightarrow{\vec{\omega}}$ of these decisions must be taken. $\mathcal{\omega}$ The view of many paediatricians is expressed by Dr Shaw when he says $\mathbb{D}$ the most humane manner for ir resolving these issues is on a case by $\omega$ case basis whereby parents and $\vec{v}$ physicians reach a decision that reflects primarily a concern for the quality of that newborn life.' $\mathrm{He}$ is bold enough to suggest some of the $\vec{c}$ factors that determine the quality of $\mathbb{D}$ life for infants. Professor Glanville Williams discusses the British $\frac{\mathbb{D}}{3}$ Infanticide Act and its application. No exactly comparable Act exists in the United States, but an American $\vec{\theta}$ law professor (Arval Morris), wh pointing out the illegality of many. current practices, suggests that law can be responsive to change as dictated not only by medicine but the common moral judgement of the community at large. Between these $\mathbb{D}$ two chapters by lawyers is a defence (by Leonard Weber, a professor of $\bar{O}$ religious studies) of the strict legal $\exists$ prohibition of infanticide.

Overall, this is an interesting compilation of views on a topic of great importance in these times. $\mathbb{D}$ The standard of the essays is $\bar{O}$ uniformly high and they are well 3 referenced with useful interpretive $\delta$ comment. The editor is to be 3 congratulated on his blend of topics and contributors. In contrast, and considering the price, the quality of book production is very low. It is printed on poor quality paper and $N$ looks like a cheap novel for the mass market rather than a serious $N$ academic publication.

A G M CAMPBELL $\underset{\sigma}{\sigma}$

\section{Tragic Choices}

Guido Calabresi and Philip Bobbit 252 pp. W W Norton and Company, New York, 1978.

The title of this book, one suspects, 
may deter its potential English readership. The tragic, off the stage, may be felt a topic to be discussed with restraint, and the introduction of this essentially private theme into the debate about public policy may seem inappropriate. Those who read the book however may begin to question such assumptions. The odd transatlantic (or perhaps transalpine) metaphor and impacted neologism apart, its authors have made a good case for their argument that a good deal can be learned by examining society's different methods of resource allocation in the context of its tragic choices.

The tragic choices which the authors have in mind are those in which an allocation of scarce resources leads not only to suffering or death for some, but also to a societal reaction of compassion, outrage or terror. Such tragic contexts, the authors point out, expose conflicts between the values by which a society determines who shall benefit (and also, perhaps more often than we like to think, the perimeters of scarcity) and other humanistic values which prize life and well-being. In such contexts the challenge is to allocate in ways which preserve the moral foundations of social collaboration; and if this challenge is successfully met, the moral contradictions may disappear. In a society which is both open and egalitarian however, such success is difficult to achieve and short-lived. Its main enemy, in the authors' view, is honesty, which exposes the subterfuges which bring temporary peace: the 'effort by which a society preserves its traditions and values while replacing them to accommodate change and necessity' are nevertheless 'civilised and sometimes ennobling'.

The book is, for the most part, an analysis of how these efforts, in the form of familiar resource-allocation methods, work-or more often fail to work-in the tragic context. It begins with pure allocation approaches: the pure market, the accountable political approach, the lottery and the customary or evolutionary approach which gives effect to these but at the same time attempts to avoid self-conscious choice. The values which each of these approaches fails to uphold are demonstrated and the discussion moves on to the ways in which society, conscious of their defects has attempted to modify them. On the one hand are the modified political devices: decentralisation, responsible agencies or juries, and further modifications of the latter. On the other are the modified markets which substitute queues for cash or attempt some form of positive discrimination. Variations and criticisms of the latter, in theory and practice, appear to be inexhaustible-as the authors admit on page II4 when they 'fear the reader will tire of endless lists of problems, endlessly enumerated, each solution breeding new problems without end.' Certainly for the general professional reader who is not an academic lawyer or economist like the authors, the going at this point is rather rough. But their hope that 'the reader who works through this extended essay will know, in the broadest sense of that word, how a society's approaches to tragic situations, in the broadest sense of that phrase, interrelate' is (broadly) justified; and the subsequent discussion, particularly of fringe markets and of the relation between the allocation of different scarce goods is an illuminating one, the latter especially on how society tries to justify, for example, saving kidney

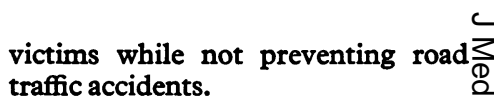

Further light on tragic choices is provided by historical perspectives $\overrightarrow{\hat{\vec{t}}}$. (mostly about conscription in the USA) and by a comparative study of the different concepts of equality operative in Italian, English ando American renal dialysis allocation $\bar{\sigma}$ policies. The authors' conclusion of $\overline{\bar{\omega}}$ the whole is that scarcity and social $\vec{\Phi}$ values alike change over time, and 2 that 'since the values endangered by any given (resource allocation) $\vec{\circ}$ approach vary, a society which:wishes to reject none of them can, $\vec{\omega}$ by moving, with a desperate grace, $\mathcal{O}$ from one approach to another, $\overline{\overline{3}}$

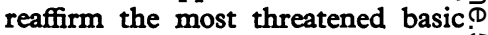
value and thereby seek to assure that its function as an underpinning of $\omega$ the society is not permanently lost'. $\vec{P}$ In other words, 'a moral society must depend on moral conflict as the basis 0 for determining morality': the only alternative 'would be the final rejection of some fundamental values.' $\mathbb{D}$

As a final apologia for their analytic efforts, Calabresi and $\frac{\mathbb{D}}{3}$ Bobbitt comment: "We do not live in the timeless days of a dog or sparrows. As we become aware of $\vec{\theta}$ what we, as a society, are doing, bear responsibility for those allocations that will be made, as wel as for what has been done in oưr names. If one understands more than $\bar{\partial}$ before for having read this essay, one can still appreciate that tragic $\mathbb{D}$ decisions need to be made and are not the easier for the understanding.' Anyone, I think, who has attempted to conceptualise the moral problems of contemporary resource allocation will recognise not only the truth of this last statement, but also the $\overparen{D}$ achievement of its authors. He may $\bar{\sigma}$ grow a little more envious of dogs and sparrows too.

KENNETH BOYD 